Thomas M. Schneidhofer, Michael Schiffinger, Wolfgang Mayrhofer

\title{
Mind the (Gender) Gap. Gender, Gender Role Types, and Their Effects on Objective Career Success over Time*
}

Drawing on ideas by Pierre Bourdieu, this paper analyzes the effects of gender and gender role type (GRT) for objective career success (i.e., income) over time. Empirically, data from two cohorts of business school graduates were analyzed with mixed linear models. Gender and GRT, both perceived as career capital, progressively affect objective career success over time, with feminine GRT hampering objective career success for both sexes. Remaining results vary between the two cohorts: findings for the younger cohort deviate more strongly from the hypotheses derived.

Key words: objective career success, longitudinal study, Bourdieu

* Thomas M. Schneidhofer, (corresponding author), assistant professor.

E-mail: thomas.schneidhofer@wu.ac.at.

Michael Schiffinger, assistant professor. E-mail: michael.schiffinger@wu.ac.at.

Wolfgang Mayrhofer, full professor. E-mail: wolfgang.mayrhofer@wu.ac.at.

Interdisciplinary Group for Management and Organisational Behaviour, WU Vienna, Althanstr. 51, 1090 Vienna, Austria. http://www.wu.ac.at/ivm.

** Article received: July 7, 2009

Revised version accepted after double blind review: April 14, 2010. 


\section{Introduction $^{1}$}

In order to understand the antecedents of career success, human capital as well as social capital variables have been examined thoroughly (Seibert/Kraimer 2001; Seibert et al. 2001). One of them is arguably gender (Melamed 1995), which is crucial in career research, leading to different career experiences (see e.g. Banks et al. 1992; Cleveland et al. 2000; Lyness/Thompson 1997; Mallon/Cohen 2001; Powell/Mainiero 1992). Nevertheless, a recent handbook in the field (Gunz/Peiperl 2007) calls for a better conceptualization of the very definition of gender in career studies (Granrose 2007: 89). On another level, researchers advocate the inclusion of the temporal aspect of careers with designs allowing for longitudinal analyses in order to prevent spurious conclusions (Judge/Kammeyer-Mueller 2007: 74). On top of this, career research all too often neglects its contextual embedment (Peiperl/Gunz 2007: 52), resulting in a call for a coherent theory combining several aspects of careers (Mayrhofer/Schneidhofer 2009).

This paper picks up these three issues. First, it operationalizes gender in a twodimensional manner with the concept of gender role types (GRT) as key independent variable (see also Abele 1994; Eckes 2004; Schruijer 2006). Thus, it overcomes the strict dichotomy of male/female and enlarges the concept of gender in career research. Second, the analyses use a panel study consisting of two cohorts of business school graduates (1990 and 2000) of a large Central European university, allowing a longitudinal analysis of income as a measure of objective career success and its changes in the course of the first twelve and seven years, respectively. Third, it draws on ideas of Pierre Bourdieu and hence allows to prescind from "men" and "women" as points of departure to "relations" as "realisations of historical acting" (Bourdieu/Wacquant 1996: 160) which explicitly includes the social context within which practices take place (Engler 2004: 223). On top of this, in the course of the interplay of social fields, capital, and habitus, gender as well as gender role type are conceptualized as conversion of accumulated capital, which is consequently a "competence" sensu Bourdieu (1998: 166).

Thus, the paper makes three contributions to management and career research: (i) It provides an additional perspective potentially leading to a more fine-grained understanding of gender as a crucial variable relevant for career outcomes that is linked with the broader context careers are embedded in - which touches management practices (e.g. gender equality efforts) as well as legal or sociological developments. (ii) The paper explicitly includes a temporal dimension built into careers. By focusing on the idea of social fields, the dynamic interplay of field, habitus and capital comes into focus. (iii) In doing so, it applies a theory building bridges across different disciplines (i.e., literature from the gender discussion, macro-sociology, management research), thus

1 The authors would like to express their gratitude to the auditorium of the 6. Jahrestagung des Arbeitskreises für empirische Arbeits- und Organisationsforschung (AKempor), as well as to Johanna Hofbauer, Katharina Pernkopf-Konhäusner, Florentine Maier and an anonymous reviewer for their helpful comments on earlier drafts of this paper. 
providing a more comprehensive picture of influences on career success while at the same time actively responding to the frequent calls for more interdisciplinarity.

\section{Theoretical lenses}

\section{The concepts of gender and gender role type in career research}

The current conceptualization of "gender" in career research is based on a dichotomization, resulting in a binary separation of men and women when addressing career and career success issues (see e.g. $\mathrm{Ng}$ et al. 2005 for a recent meta-study). In general, it is the latter who come off comparatively badly in terms of career outcomes: Women are poorly represented in executive ranks in organizations (Tharenou 1999), because they apparently face a glass ceiling (Corsun/Costen 2001), while males (in female occupations) may take advantage of a glass escalator (Williams 1992). Throughout Europe, women earn less than men (OECD 2008: 168), even if part time employment, position and parental leave are controlled for (Eagly/Carley 2007). On top of this, even if women and men are "parallelized" retrospectively as far as the antecedents of career success are concerned, i.e. they do not differ in respect to socio-demographic details, personality structure, career tactics, and structural conditions (e.g., age, cohort), male business school graduates earn about 73000 Euro more than their female counterparts within the first ten career years (Strunk/Hermann 2009: 251). As a result, even if female employees had - or did - "all the right stuff" (Stroh et al. 1992), i.e. proving their career mobility adequately, and being as well educated as their male colleagues, women lag behind in terms of objective career success.

However, this dichotomization of women and men already conceptually includes a system of homological antagonisms - (Bourdieu 2005: 18), which equals sex category (man/woman, see West/Zimmerman 1987) with the psycho-social realization - or projection - of "femininity" and "masculinity" in a given culture ("gender", Abele 1994: 30). With other words, it excludes the possibility of thinking, feeling, acting, or reacting (as well as of being perceived) differently than the rest of the sex category one is associated with. Men and women consequently appear as opponents in the career game, who are either advantaged or disadvantaged per se, highlighting differences instead of mutual similarities (Bock 2004).

Correspondingly, career research most often does not refer to the "little (biological) difference" as producing the (big) difference in career success, but the conceptual dualism is allegedly justified by different socializations men and women experience (Abele 1994). Subsequently, the influence of gender is conceptualized as indirect and may be classified alongside the debate of the primacy of social versus human capital: might that be qua resulting opportunity structures (Astin 1984; Lemons/Danehower 1996; Lobel/St. Clair 1992; Tsui/Gutek 1984), like discrimination, or patronage (like mentoring), as opposed to different occupational motivations (Bowen/Hisrich 1986; Farmer 1985), states (Nelson/Quick 1985), or attitudes (Correll 2001; Procter/Padfield 1999).

However, this paper seeks to broaden this perspective with an additional theoretical perspective, reconstructing gender as an aspect of one's self-concept (Eckes 2004), which is called Gender Role Orientation (Bem 1993; Spence/Helmreich 1978). This concept refers to the way men and women tend to describe themselves on two dimen- 
sions (Spence et al. 1974; Spence et al. 1979), emphasizing both masculinity or femininity to a certain extent in a single person. Eventually, this enables researchers to place gender in a two dimensional field (Abele 1994: 39), deriving Gender Role Types according to the interplay of masculinity and femininity.

Figure 1: Gender role types (see also Abele, 1994: 39)

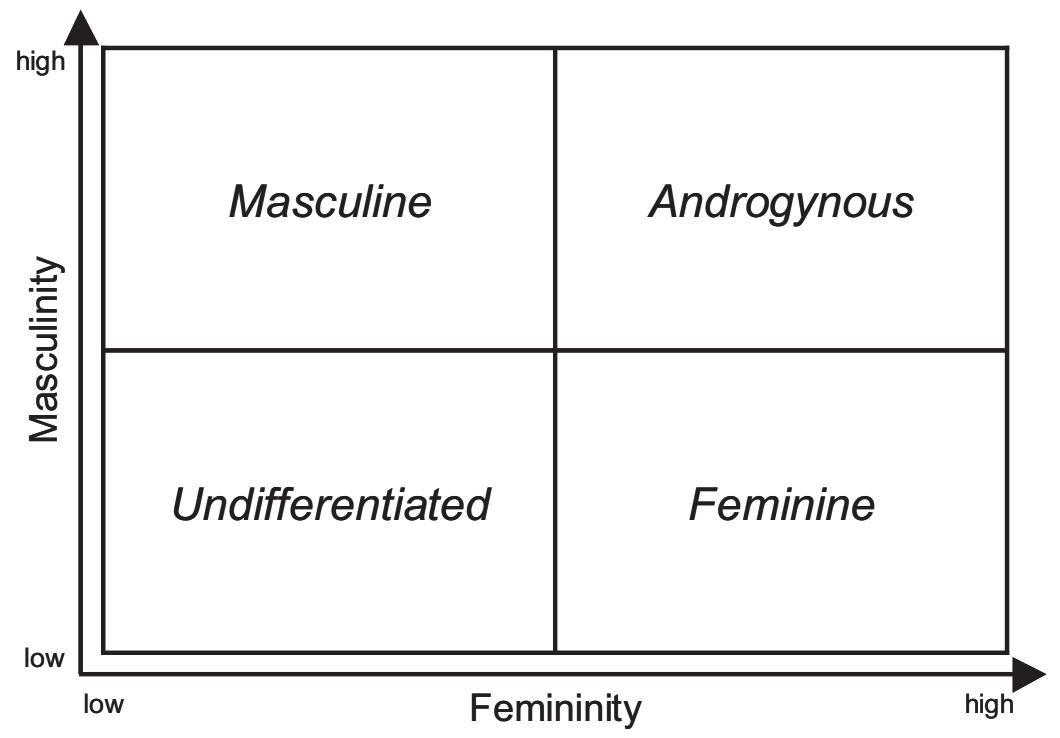

Masculine gender-typed persons score high on stereotypically male oriented scales, whereas they score low on stereotypically female oriented scales, the reverse is true for feminine gender-typed persons. People who score low on both scales are undifferentiated, people scoring high on both are labelled androgynous (see also Schneidhofer et al. 2009). Instead of a polarization as two distinct endpoints of a continuum (dichotomy), gender is reconstructed as a duality within which men and women may realize more or less masculine or feminine characteristics, or behaviour.

An overview of studies using this lens on career orientations is provided in Abele (1994: 32 ff.) but limited in quantity and unrelated to the subject of (objective) career success. Nevertheless, they have in common that gender role orientation appears to be a more important predictor of occupational orientation than sex. Additionally, Abele (1994: 115) concludes for her study of two German university student populations that sex is "no suitable differentiating criterion for career orientations" at all.

This is hardly surprising when applying Bourdieu's conceptualisation of sex category as an essential yet insufficient classification basis for social practices: There is no useful construction, or reconstruction, of sex and gender while ignoring the social practice of actors. To illustrate this point, we turn to the concepts of career fields (Iellatchitch et al. 2001; Iellatchitch et al. 2003), career habitus (Mayrhofer et al. 2005; Mayrhofer et al. 2007c) and career capital (Mayrhofer et al. 2007a). 


\section{A theory of career practices}

Career practices are the result of the reflexive interplay of career field, career habitus and career capital. They follow an economy (but not: the economy) of action on several dimensions.

Figure 2: Field, habitus, and capital as aspects of macro-, meso-, or micro-level focus (own illustration based on Özbilgin/Tatli, 2005: 861 ff.)

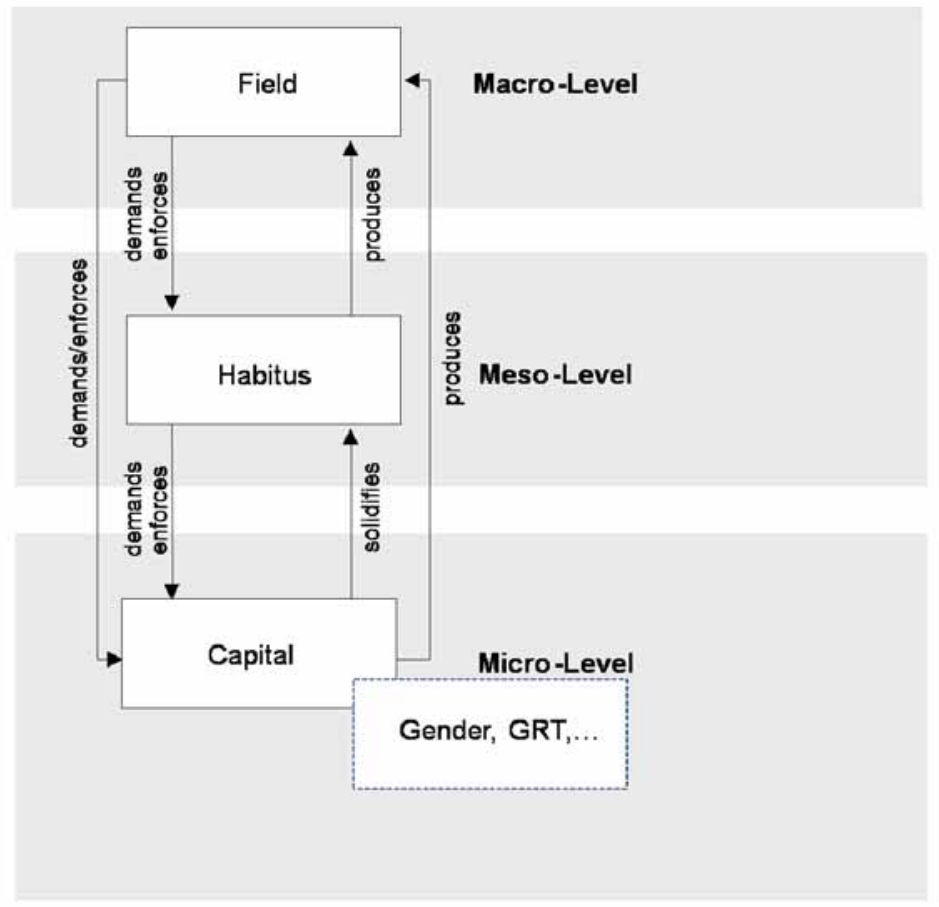

Career fields in general are the social context within which individual members of the work force, who are equipped with a specific portfolio of field-relevant capital try to maintain or improve their place in the given and unfolding network of work related positions ("relations") through a patterned set of practices which are enabled and constrained by the rules of the field and, in turn, contribute to the shaping of these rules. It is important to notice, however, that careers are not a field, but unfold within a field, and emerge as a sequence of positions derived from work related efforts. These career fields are embedded in the social space and constituted by an illusio (Bourdieu/Wacquant 1996: 149), which denotes a specific implicit concern of actors for the objects of interests at stake.

In the case of the managerial career field, illusio refers to "advancing" one's trajectory in this field in the broadest sense of the word. This includes, among others, aspirations of career and career strategies as well as the perception of career outcomes. Additionally, this concern depends on the position one occupies in the career field (heretic/orthodox, dominant/dominated). Those agents already having hegemony 
over the field aim at conserving or expanding their power over the structure of the field. New agents, by contrast, are seeking to gain influence. Responsible for (and, strictly speaking, resulting from) this structure is career habitus, which denotes the "horizon of opportunities" (Bourdieu 1993: 33) developed in order to show strategic behaviours (see also Krais 1985; Müller 1986) according to the rules of this field.

This career habitus is the product of internalization, the incorporation of the immanent necessity of advancing within this field (Bourdieu/Wacquant 1992: 102). It is bodily (sic!) incarnated history of the career field, which is naturalized but negated as such, because it is realized as second nature (Bourdieu 1976: 171). Habitus creates, and is reinforced by, dispositions the actors develop (Lahire 2003). In turn, (career) habitus shapes the (career) field in a recursive manner as well. It structures the strategies agents may develop according to their position in the field, and the career capital portfolio they possess. This is important, because the history of the managerial career field is characterized by masculine domination (as most social fields, see Bourdieu 2001), which subtly gratifies certain attitudes and behaviors, and punishes others. These attitudes and behaviours are due to the expected, or projected, "exchange rates" of accumulated career capital into other types of capital (e.g., economic capital like objective career success).

Career Capital is the sort of capital valued within the field of career. Since Bourdieu perceives the field in analogy to a game (e.g. Bourdieu/Wacquant 1992: 98ff), capital is the resource actors may act upon in order to advance within the field. Equipped with a unique portfolio of capital, each individual agent is located in the field of career depending on the amount of capital as well as with the composition of the portfolio, i.e. the relative parts of the different sorts of capital, and the temporary development of both. Again, it is the field, and the other actors' habitus, which recognizes the alleged value of the capital applied (or not), and the relation of its translation into other types of capital (like economic, cultural, social, or symbolic capital, see Bourdieu 1986). Gender, as well as GRT, may then be conceived as representing aspects of career capital actors are endowed with (Schneidhofer et al. 2009).

However, this interplay shows a dynamic quality reflecting the focal relationship between work and time which is essential for conceptualising careers (Arthur et al. 1989). As a consequence, the relative value of career capital (of any kind) changes throughout the trajectory. Hence, it is necessary to apply a longitudinal design in order to capture the time perspective inherent to this development.

This is necessary because the individual strategies derived from the logic of the career field (and vice versa) only develop over time, which means that a different set of capital is valued at the beginning of one's career compared to later career years. Hence, a gender pay gap is likely to appear only over time.

In a nutshell, the research question arising is how gender and GRT, perceived as career capital, affect objective career success in the managerial career field over time, and how both interrelate in this respect.

\section{Hypotheses}

The managerial career field emerged during industrial revolution. Within this period, two spheres of production developed (Beck 1983; Beck-Gernsheim 1984; Durkheim 
2008 [1893]). On the one hand, a private (reproductive) sphere arose, which spanned among others, private life, and family. On the other hand, a public (productive) sphere came up, including work, and career. Each sphere was associated with one sex category exclusively, stereotyping their elements with the needs to succeed there (Strunk et al. 2005: 215). This used to be nurturance and interpersonal harmony for women, and ambition and achievement for men (Thomas/Inkson 2007: 457). Note that this does not imply that it is "nature", which is at work here: the difference is only naturalized, indicating that it appears as natural, for it is the product of the field, and their actors within, but it is, in essence, a social phenomenon.

However, in the field of career, variables constituting the public sphere were used in order to construct a "masculine sphere" (Engler 2004: 229) to enable masculine hegemony within the field. This means, as a consequence, that the assumption indicated above, that women are disadvantaged in terms of objective career success, may also be derived from a Bourdieuian perspective as well. But not because women wouldn't have the right stuff, rather it appears as a somatization of a cultural arbitrariness through the masculinization of male and the feminization of female bodies (Bourdieu/Wacquant 1996: 210).

Nevertheless, it is easy to find female success stories in the literature (Eagly/Carley 2007), which shifts attention to certain types of femininity (Schruijer 2006). This may partly be due to the rational nature which is embedded in the very career concept (Hermann 2004; see also Thomas/Inkson 2007: 456), and which disadvantages certain types of people: those with communion rather than agency-based career concepts (Marshall 1989). As a consequence, it may be concluded that certain types of males are also disadvantaged in the course of the career game.

Additionally, since "the sense of the game" (Emirbayer/Johnson 2008: 27) is not "given" from the beginning, but has to be developed according to (the recognition of) career capital, like gender and GRT, this objective career success gap likely arises over time only, and is not apparent from the beginning of one's trajectory. Nevertheless, men and women who are femininely typed, face disadvantages in the course of their careers. "Doing gender while doing the job" (Leidner 1991) then has a twofold meaning: (i) gender, as well as GRT, perceived as career capital, unfolds due to the trajectory and (ii) in the course of one's trajectory:

H1: $\quad$ For both sexes, the feminine GRT achieves the least objective career success over time.

In contrast, men who play the game according to the rules of rationality implied face the strongest advantage. This is due to Bourdieus "principle of isotimy" (Bourdieu 1990: 101) derived from the game metaphor. It refers to the equality in honour necessary to be an opponent on a par. Essentially, the principle implies that the actors having hegemony over the field aim at perpetuating their domination. Hence, they only play against heretics if they may win as well. But this is not the case if they play with actors not having the same honour as they possess: they would lose anyway, because potentially resulting disgrace of losing does not represent any harm for these heretics (Bourdieu 1976: 11). 
Because they make it to the important career games, masculine men face advantages in the course of their trajectories. Again, the time perspective is important here: At the beginning, there are no significant differences to display, because the 'appropriate' career habitus has to be developed, and is not attached to sex category only.

H2: $\quad$ For males, the masculine GRT achieves the most objective career success over time.

Studies show that "blending agency with communion" (Eagly/Carley 2007: 163) enables females to play according to the rules of the game encoded in the career habitus, but also to avoid resistance due to gender-atypical behaviour (see also Spence et al. 1975; Bem 1977; Spence/Helmreich 1978; Halberstam 1998). So, in contrast to Bourdieu, who states that women simply avoid the most valued games (Bourdieu/Wacquant 1992) or only love men who have power (while men love power, Bourdieu 1997: 201) and thus reduce themselves to spectators of the game voluntarily, we suppose that androgynous women prevail.

H3: $\quad$ For females, the androgynous GRT achieves the most objective career success over time.

\section{Methodology}

\section{Research design}

As our dependent variable (income) was measured for several consecutive career years and our hypotheses include the longitudinal effect of gender and GRT, we analyzed the proposed effects of time, gender, and GRT on income with the mixed linear models procedure (e.g., McCulloch/Searle 2001) incorporated in SPSS, with work years not only included as a fixed effect but also as an autoregressive term (AR1) in all models. While the purpose of this method and interpretation of the results are similar to general linear models and/or linear regression, it can handle data correlation stemming from repeated measures per case even for unbalanced longitudinal data (e.g., Jennrich/Schluchter 1986: 806) and is therefore well suited to our data structure.

As the hypotheses assume that the effects of gender and GRT develop over time, the fitted models not only include gender, GRT, and work year as fixed main effects, but the gender and GRT x work year interactions as well. In addition, an explorative gender x GRT and gender x GRT x work year interaction term was added, too. For income, outliers were filtered out for each cohort and each work year, separately for women and men, before conducting the analyses.

\section{Data collection and sample}

The analyzed data come from two samples of business school graduates from a major European university, with graduation around 1990 and 2000, respectively, and are part of the Vienna Career Panel Project (ViCaPP, see www.vicapp.at). The 1990 cohort consists of 199 persons (39\% women, mean age 45 years \pm 3.4 ). The 2000 cohort comprises 426 persons (48\% women, mean age 36 years \pm 3.5$) 2$. In both cohorts, women are on average one year younger than men. Concerning age and gender pro-

2 Of these 426 persons, 72 come from a polytechnic sample of the same graduation year. 
portions, both cohorts are representative for the respective graduates of the whole university.

Owing to the rather time-consuming data collection, it was split into two phases for all cohorts. As the project started in 2000, different approaches were necessary for the 1990 as opposed to the 2000 cohort. Both cohorts were sent a questionnaire containing psychometric scales about career aspiration, career tactics, personality and jobrelated personality as well as sociodemographic data concerning the upbringing, e.g. urban versus rural environment, parents' education and occupation, leisure activities during childhood and youth. The response rate for the 2000 cohort was close to $20 \%$. For the 1990 cohort, sample size was fixed before and not all graduates' addresses were available, so a response rate cannot be sensibly reported here.

The actual career survey was conducted separately. For the 1990 cohort, it consisted of questionnaire-based face-to-face interviews, starting with a retrospective chronological tabulation of all previously held jobs since graduation, which was the basis of several ratings for each year (number of subordinates, job centrality, income, job satisfaction etc.) as well as additional information on each job (e.g., type of contract, amount of weekly work hours, type of organization). For the 2000 cohort, the same information was gathered with annual surveys from 2002 on. The following analyses include twelve work years for the 1990 cohort and up to seven work years for the 2000 cohort (not all panel members participated in each survey wave).

The sample for the scale analyses concerning masculinity and femininity (next section) is much larger (almost 1400 cases) and includes not only all survey participants from the university but several additional groups as well. Of this sample, 40\% are female and the mean age here is 39 years $( \pm 9.4)$.

\section{Measures}

The most frequently used methods to derive gender roles are the "Adjective Check List" (Williams/Bennett 1975), the "Sex-Role Stereotype Questionnaire" (Rosenkrantz et al., 1968), the "(Extended) Personal Attributes Questionnaire" (Spence et al. 1979), and the "Bem Sex Role Inventory" (Bem 1974) (cf. Eckes 2004: 166). As the idea of connecting masculinity and femininity to gender and career outcomes arose after data collection, we had to rely on the psychometric items and scales contained in the questionnaire (see below).

Still, we tried a theory-driven approach, taking dimensions of feminine and masculine behavior identified in the literature (Spence/Helmreich 1978; Runge et al. 1981; Spence/Buckner 2000) and looking for items that corresponded to each of these dimensions. Apart from attempting to maximize face validity, we also wanted the resulting scales to have decent consistency values and not to intercorrelate too strongly. The available items came from two scales of the German NEO-FFI (emotional stability and conscientiousness; Borkenau/Ostendorf 1993), the Bochumer Inventory of jobrelated personality (leadership motivation, achievement orientation, team orientation, flexibility etc.; Hossiep/Paschen 1998), a self-monitoring scale (Snyder 1974; Schiefle 1990) as well as five scales measuring career-oriented political behavior and four scales measuring career aspirations (Schiffinger/Strunk 2003). 
The elements of positive feminine behavior identified in Runge et al. (1981) are (each followed by the number of items measuring this aspect and one sample item from the questionnaire; (-) stands for a reverse-coded item):

- Emotional (3): "I am considered to be a reserved person.” (-)

- Devotes self to others (4): "Being able to pursue my activities without having to adjust to others is important to me." (-)

- Gentle (2): "If necessary, I overcome resistance against my plans by a trial of strength." (-)

- Helpful (3): "My colleagues see me as a lone warrior." (-)

- Kind (2): "I strictly limit my relations to co-workers to a professional level." (-)

- Aware of feelings (2): "I find it difficult to criticize others."

- Understanding (1): "I don't like making decisions that trammel others."

- Warm (4): "It takes me a while to make friends." (-)

The elements of positive masculine behavior are (Runge et al. 1981):

- Independent (2): "I consistently avoid cliques and old boys' networks."

- Active (3): "When in company, I leave it to others to tell jokes and stories." (-)

- Decisive (2): "T like being in charge of important decisions."

- Never gives up (2): "I am too easily discouraged and prone to giving up when something goes wrong." (-)

- Self-confident (3): "During meetings I often assume chairmanship even without being a formal leader."

- Feels superior (3): "I am a role model to others."

- Stands up under pressure (2): "I am not easily worried."

It might be interesting to note that finding items for the femininity dimensions in these "career-related" scales was notedly harder (and mostly resulted in using reversecoded items) than finding masculinity items. Also, item face validity for some aspects might admittedly be somewhat problematic given the limited selection of appropriate items. By contrast, the thematic overlapping of some is in accordance with the original concept, where both femininity and masculinity are reported as being empirically unidimensional (Helmreich et al. 1981, in Runge et al. 1981: 148). One also has to bear in mind that to our knowledge the existing scales for measuring GRT are not quite on the same level as most established instruments as far as scale properties are concerned. For instance, while the Cronbach alpha values for our scales are below desirable levels (.77 for masculinity, .67 for femininity), they are still above the consistency values reported for the original scales (Runge et al. 1981: 153). Against this backdrop, other explorative analyses concerning the acceptability of the scales offer at least limited support to the effort put forward here. As femininity and masculinity are two largely independent dimensions according to the literature, the scale intercorrelation should be moderate, which is the case with a mere .23. Likewise, the mean differences between men and women are qualitatively plausible and in agreement with the theory (Runge et al. 1981: 154), but not too pronounced. On a theoretical range from 1 to 6 , 
the means were 3.82 (women) vs. 3.7 (men) for femininity, and 4.08 (women) vs. 4.33 (men) for masculinity. Some further support comes from a small validation sample of 32 women and 24 men who were asked to rate themselves on our GRT scales as well as the GEPAQ (Runge et al. 1981). Our femininity scale had a correlation of .51 ( $\mathrm{p}<$ 0.01) with the GEPAQ femininity scale as opposed to -.09 with the GEPAQ masculinity scale. (For our masculinity scale, the respective correlations were .75 with the concurrent and -.16 with the "wrong" GEPAQ scale).

An explorative factor analysis (ML extraction) with a forced two-factor solution provides some additional support for item allocation and scale independence: for a Varimax-rotated solution only two items per scale $(9.5 \%$ for femininity and $11.8 \%$ for masculinity) had higher loadings on the 'wrong' factor. A confirmatory factor analysis on the same dataset $(n=1399)$ yields mixed results. The chi-square statistic clearly rejects the model (chi-square $=6419.9$, $\mathrm{df}=664$ ), but this is probably a result of the rather large sample size, too. RMSEA (.08) and SRMR (.09) values indicate an acceptable fit, while NNFI (.57) and CFI (.59) clearly fall short of desirable standards (Schermelleh-Engel et al. 2003: 52). By and large, while not completely satisfactory, the scales developed here seem on par with existing measurements of gender role types despite their "maverick" origin.

\section{Other measures}

GRT was assigned by a median split (following Spence et al. 1979) of the abovementioned positive femininity (fem) and masculinity (mas) dimensions, with four resulting combinations: undifferentiated (low fem, low mas), feminine (high fem, low mas), masculine (low fem, high mas), and androgynous (high fem, high mas). While entailing a loss of information compared to keeping the scales, the median split follows pertinent literature concerning GRT (Helmreich et al. 1981; Spence et al. 1974; Spence et al. 1979; Spence 1991; Spence/Buckner 2000), fits better with the hypotheses and facilitates interpretation of the statistical models (see results section). The median split was done seperately for each of the two cohorts, as they had different median values and using the same value for both cohorts would have resulted in a downright inequal distribution and very few cases for some GRT. However, when performing the analyses with another median split based on the large sample used for scale development, the effects remained unchanged except for one interaction term in the 2000 cohort which becomes insignificant.

Income refers to the gross yearly income as reported by the participants. Selfreported measures are always prone to biases, especially single-item measures. Yet, Podsakoff et al. (1986: 532f.) find that variables which can be reality checked are usually only marginally distorted. Judge et al. (1995) report a mere 1\% difference between self- and archival reports of salary in a sample of 1,338 executives (see also Seibert/Kraimer 2001: 8). Employment status (employed, self-employed or on (parental) leave) and weekly work hours are controlled for in the analyses, too. Although not presented here, we also calculated models including industry and marital status (single versus couple; only for the 2000 cohort as too few cases were available here in the 1990 cohort) to check whether this would change the statistical significance of the observed effects, which was not the case. 


\section{Results}

Table 1 shows the results of the longitudinal models for both cohorts (parameter estimates in Euro with standard error and fixed effect $\mathrm{F}$ and $\mathrm{p}$ values). For gender and GRT, male gender and androgynous GRT were the reference categories for which no extra estimates were computed, so to shorten the output, only the other categories are reported in the table.

Table 1: Parameter estimates and significance of effects for income models

\begin{tabular}{|c|c|c|c|c|c|c|}
\hline \multirow{3}{*}{$\begin{array}{l}\text { Predictor term } \\
\text { (Constant) }\end{array}$} & \multirow{2}{*}{\multicolumn{2}{|c|}{$\begin{array}{c}1990 \text { cohort }(n=178) \\
\text { Par. estimate }(\text { s.e. })\end{array}$}} & \multirow{3}{*}{$\begin{array}{l}\begin{array}{c}\text { F value of } \\
\text { effect }(p)\end{array} \\
15.27^{* *}\end{array}$} & \multirow{2}{*}{\multicolumn{2}{|c|}{$\begin{array}{c}2000 \text { cohort }(n=395) \\
\text { Par. estimate (s.e.) }\end{array}$}} & \multirow{3}{*}{$\begin{array}{r}\begin{array}{r}\text { F value of } \\
\text { effect }(p)\end{array} \\
6.57^{*}\end{array}$} \\
\hline & & & & & & \\
\hline & 10263.5 & $(6114,2)$ & & 3842.4 & $(3005.6)$ & \\
\hline Work year & 5479.0 & $(515,0)$ & 326,38 ** & 7412.0 & $(543.5)$ & $378.85^{* *}$ \\
\hline Gender: female (vs. male) & -170.5 & $(10306,3)$ & .04 & -5688.5 & $(4220.8)$ & .70 \\
\hline GRT: indifferent (vs. androg.) & 3300.6 & $(8111,3)$ & .21 & -2145.7 & $(3654.6)$ & .33 \\
\hline GRT: feminine (vs. androg.) & 4443.2 & $(9464,8)$ & & 1545.1 & $(4068.4)$ & \\
\hline GRT: masculine (vs. androg.) & 6129.6 & $(8307,8)$ & & -2331.7 & $(3664.5)$ & \\
\hline Female gender $x$ work year (wy) & 425.2 & $(913,9)$ & 10.66 ** & -2479.9 & $(938.6)$ & $14.05^{\star \star}$ \\
\hline GRT ind. (vs. androg.) $x$ wy & -749.6 & $(707.5)$ & 13.00 ** & -1909.2 & $(823.7)$ & $6.48^{* *}$ \\
\hline GRT fem. (vs. androg.) x wy & -2393.0 & $(828.6)$ & & -4000.4 & $(1021.0)$ & \\
\hline GRT mas. (vs. androg.) x wy & 1359.5 & (729.1) & & -882.9 & (821.6) & \\
\hline Female gender $x$ GRT ind. & 2483.8 & (14362.2) & .17 & 9385.7 & $(5650.0)$ & 1.25 \\
\hline Female gender $x$ GRT fem. & 1540.5 & $(14500.6)$ & & 559.2 & $(6005.2)$ & \\
\hline Female gender x GRT mas. & -7298.1 & $(15268.7)$ & & 5843.2 & $(6107.9)$ & \\
\hline Female gender $x$ GRT ind. $x$ wy & -2999.0 & $(1278.3)$ & $2.22+$ & -870.3 & $(1260.6)$ & $2.86^{*}$ \\
\hline Female gender $x$ GRT fem. $x$ wy & -2016.4 & $(1282.6)$ & & 3099.9 & $(1438.3)$ & \\
\hline Female gender $x$ GRT mas. $x$ wy & -2834.9 & $(1389.0)$ & & 326.3 & $(1394.4)$ & \\
\hline Self-employment & -1907.8 & $(2250.8)$ & 3.28 * & 9132.7 & (2955.7) & $4.82^{* *}$ \\
\hline Parental leave & -4089.6 & $(1621.6)$ & & -484.8 & $(2093.8)$ & \\
\hline Per weekly work hour & 85.3 & $(39.0)$ & 4.77 * & 495.6 & (39.4) & $158.41^{* *}$ \\
\hline
\end{tabular}

$+p<0.1^{*} p<0.05^{* *} p<0.01$

It is apparent that neither gender nor GRT have an effect at the outset in these models, but both predictors become significant over time, which is consistent with prior analyses (e.g., Strunk et al. 2005). The statistically significant gender x GRT x work year term (on the 10\% level only for the 1990 cohort) suggests that the influence of GRT on income is slightly different for women compared to men. Not surprisingly, work experience (measured by work year), employment status and weekly work hours are important predictors of income as well.

Like in regression or general linear models, the estimated value for the dependent variable can be obtained by adding the respective parameter estimates to the constant term. As obtaining the values from the table is a bit cumbersome, figure 3 shows the 
predicted income values for the most and least "profitable" GRT for both cohorts (including all combinations would result in a rather confusing chart).

Figure 3: Income development (predicted means) of the most and least successful GRT
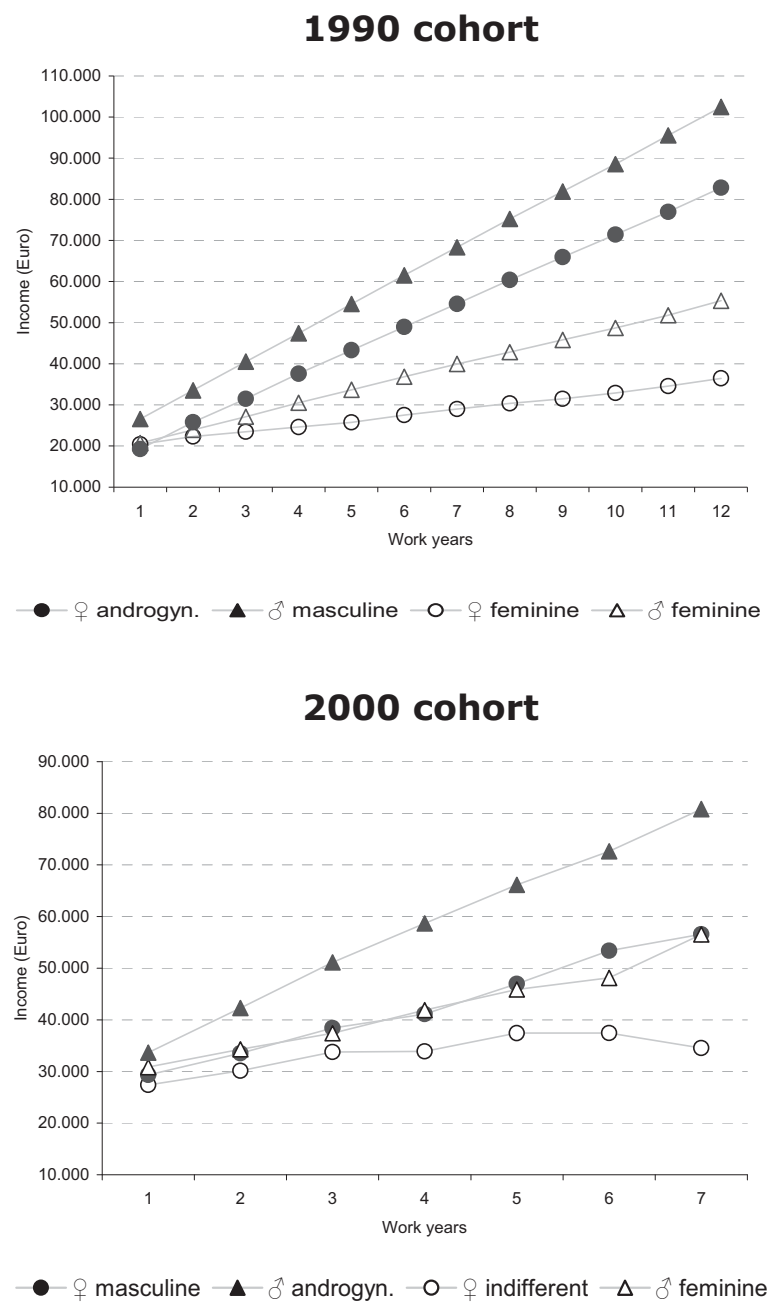

The charts illustrate how the effect of both gender and GRT develops over time, and also show that different GRT are most and least successful in terms of income for women and men, with the results varying somewhat between cohorts. In the 1990 cohort, masculine men and androgynous women had the highest income, apparently in accordance with $\mathrm{H} 2$ and H3, while a feminine GRT minimizes income for both women and men, as predicted in H1.

In the 2000 cohort, the most "profitable" GRT are reversed: masculine women and androgynous men are the groups with the highest respective income, and while being feminine still penalizes men most, it is indifferent (and not feminine) women 
that earn the least. In addition, according to the results in the 1990 cohort, the most successful women's GRT (androgynous) has more income than the least successful men's GRT (feminine). But in the 2000 cohort even the most successful women's GRT just barely closes in on the least successful men's GRT. That would suggest an increasing gender pay gap (regardless of GRT), an assumption that was corroborated in a further study (Mayrhofer et al. 2009).

Especially in the 2000 cohort, the predictors in the model explain a fair amount of variance in income. There are no $\mathrm{R}$ square values for mixed linear models, but an alternative with similar properties and interpretation called marginal $\mathrm{R}$ square (e.g., Zheng 2000: 1269). The marginal $\mathrm{R}$ square values for the two models are .36 for the 1990 cohort and .50 for the 2000 cohort.

Getting back to our hypotheses, none of them are supported for the 2000 cohort: the feminine GRT is not the "least remunerated" one for both sexes; it is the androgynous and not the masculine GRT who shows the highest earnings among men, while for the women in this cohort the masculine GRT appears most promising instead of the androgynous one. In the 1990 cohort, while the female GRT is indeed the least successful one in terms of income, testing the "female" parameter estimate for the GRT x work year term against the "next worst earning" GRT shows that H1 is just supported for the male part of the sample (and only on the 10\% level). H2 appears to be supported for the 1990 men, with the masculine GRT showing the highest earnings, but the difference to the androgynous GRT among the male part of the 1990 sample is not significant (unlike the difference to the undifferentiated and feminine GRT). The same goes for H3, where androgynous women attain the most income, but again the difference to the male GRT is not statistically significant over time (while again, the undifferentiated and feminine GRT do earn significantly less over time).

Despite this limited support for the proposed hypotheses, the results are interesting insofar as they suggest that a) not only do both gender and GRT affect income, but in addition the GRT effect depends on the person's gender; b) the most and least "lucrative" GRT not only depends on gender but also on cohort; c) the effects of both gender and GRT are relatively negligible at the outset but develop over time.

\section{Limitations}

The present study obviously has some shortcomings, most of which have already briefly been mentioned: the use of self-report measures for the dependent variable, a rather specific sample of highly educated business school graduates, the difference in survey design between the two cohorts (real-time vs. retrospective), and the potentially debatable properties of our scales measuring gender role orientation. Another point could be made here concerning the idea of GRT itself: is the concept devised by Spence and Helmreich (1978) which we tried to reproduce still up to date or does it (already) lack thematic relevance? It is important to notice, however, that GRT appears to be a stable concept, both interculturally (Runge et al. 1981; Williams/Best 1990) and temporally (Bergen/Williams 1991; Spence/Buckner 2000).

Additionally, the term "androgynous" appears old fashioned and theoretically overcome (Bock 2004: 101). This is due to the alleged masculine notion underneath 
the nomology, and the perpetuation of the traditional "masculine" and "feminine" concepts in the union of both as a consequence (Bock 2004). However, we decided to keep the term and to use it in an epistemological opened manner in order to connect with the classical theory of GRT, and to work with the empirical data deriving from the idea - just like Bourdieu would probably do.

Finally, critical readers may miss the concept of subjective career success in our analyses (Hughes, 1937; Heslin 2005). Then again, literature strongly suggests that subjective and objective career success are conceptually distinct aspects $(\mathrm{Ng}$ et al. 2005) requesting different approaches (Nicholson/DeWaal-Andrews 2005; Reichel et al. 2006). Of course, even though the topic of career satisfaction along with the fundamentally different processes associated with internal coping were explicitly not the issue of our paper, they would certainly offer fruitful avenues for further research.

\section{Conclusion and implications}

Conceptualizing gender role orientation as part of individuals' career capital emphasizes the embedment of careers in the broader cultural and institutional context. Capital, as well as habitus, is not a given entity that has a value regardless of the field it is embedded in, but receives its specific significance from the properties of the field. For example, while one field might regard social capital such as access to social networks as valuable symbolic capital which is crucial for achieving prominent positions in this field, other fields might more rely on formal certificates.

Over the past four decades, gender has been a major theme when looking at the context of work careers (Mayrhofer et al. 2007b) as well as at the level of society, addressing issues such as the relationship between men and women, the role of women in society, or the make-up of partnerships and families. Arguably, the effects of these developments constitute one of the major changes that industrialized countries have witnessed over the past decades. Among others, this also has partly changed the views of what it takes to be successful in one's job. The middle-aged white male as the prototype for occupational success still exists. However, it has been supplemented by other views, coming from the diversity discussion, from the call to men to transcend the classical male role of being the sole breadwinner and to include more "feminine and soft" characteristics as reflected in numerous popular books about reconciling the sexes, from the increasing availability of successful female role models in business and in politics, or from the calls for alternative ways of doing business in terms of sustainability requiring different competencies beyond the "masculine and hard" approach of "higher-faster-farther". Consequently, throughout the 1990s, a new masculine paradigm emerged called metrosexuality. This refers to heterosexual men caring for their appearance and adopting sensitiveness, reflexiveness, and expressiveness to their personal portfolio (Whithehead 2008: 238). Style idols like David Beckham, or Johnny Depp's Jack Sparrow exemplify the "mirror men" (Simpson 1994) now entering the stage. Slowly, this development is reflected in career field's logic, changing "successful" career habitus, as well as the career capital necessary to succeed as indicated in cohort 2000 results. Women, on the contrary, may face the need - or the preparedness - to supplement their personal portfolio with instrumental, and achievement 
oriented styles (Gaschke 2005). Ostensibly, similar contextual issues may also be at work here.

In terms of GRT and their relationship to career success in different cohorts of individuals entering the labor market 10 years apart, these developments lead to three major assumptions. First, for both men and women displaying a clearly masculine element in one's GRT as part of the individual habitus is still rewarded by the career field business school graduates are in. Despite the developments pointed out, doing business is still heavily influenced by "masculine" values and patterns such as being active, self-confident and risk-taking, and this is especially true for mere expressivity being punished.

Second, for both sexes integrating the respective counterpart in one's portfolio becomes increasingly success relevant, i.e. compared to the 1990 cohort, men and women in the 2000 cohort are better off with a more "holistic" GRT.

Third, although both genders align more closely, this is not accompanied by a decrease in gender pay gap from a sex category point of view - on the contrary, arguably women in 2000 cohort do not come as close to men, as they did in 1990 (see also Mayrhofer et al. 2009; Schneidhofer et al. 2010).

\section{References}

Abele, A. E. (1994): Karriereorientierungen angehender Akademikerinnen und Akademiker. Bielefeld: USP.

Arthur, M. B./Hall, D. T./Lawrence, B. S. (1989): Generating new directions in career theory: The case for a transdisciplinary approach. In: M. B. Arthur, D. T. Hall and B. S. Lawrence, Handbook of career theory. Cambridge, England: Cambridge University Press: 7-25.

Astin, H. S. (1984): The meaning of work in women's lives: A socio-psychological model of career choice and work behavior. In: The Counseling Psychologist, 12(4): 117-126.

Banks, M./Bates, I./Breakwell, G./Bynner, J./Emler, N./Jamieson, L./Roberts, K. (1992): Careers and identities. Philadelphia: Open University Press.

Beck-Gernsheim, E. (1984): Individualisierungstheorien: Veränderungen des Lebenslaufs in der Moderne. In: H. Keupp, Zugänge zum Subjekt. Perspektiven einer reflexiven Sozialpsychologie. Frankfurt a. Main: Suhrkamp: 125-146.

Beck, U. (1983): Jenseits von Stand und Klasse? Soziale Ungleichheiten, gesellschaftliche Individualisierungsprozesse und die Entstehung neuer sozialer Formationen und Identitäten. In: R. Kreckel, Soziale Ungleichheiten, Soziale Welt. Göttingen: Schwarz: 35-47.

Bem, S. L. (1974): The measurement of psychological androgyny. In: Journal of Consulting and Clinical Psychology, 42(2): 155-162.

Bem, S. L. (1977): On the utility of alternate procedures for assessing psychological androgyny. In: Journal of Consulting and Clinical Psychology, 45: 196-205.

Bem, S. L. (1993): The Lenses of Gender. New Haven: Yale University Press.

Bergen, D. J./Williams, J. E. (1991): Sex Stereotypes in the United States Revisited: 1972-1988. In: Sex Roles, 24: 413-423.

Bock, U. (2004): Androgynie: Von Einheit und Vollkommenheit zu Vielfalt und Differenz. In: R. Becker and B. Kortendiek, Handbuch Frauen- und Geschlechterforschung. Theorie, Methoden, Empirie. Wiesbaden: Verlag für Sozialwissenschaften: 99-103.

Borkenau, P./Ostendorf, F. (1993): NEO-Fünf-Faktoren Inventar (NEO-FFI) nach Costa und McCrae. Handanweisung. Göttingen: Hogrefe Verlag für Psychologie.

Bourdieu, P. (1976): Entwurf einer Theorie der Praxis auf der ethnologischen Grundlage der kabylischen Gesellschaft. Frankfurt a. Main: Suhrkamp. 
Bourdieu, P. (1986): The Forms of Capital. In: J. G. Richardson, Handbook of Theory and Research for the Sociology of Education. New York: 241-258.

Bourdieu, P. (1990): The Logic of Practice. Stanford, CA: Stanford University Press.

Bourdieu, P./Wacquant, L. J. D. (1992): An Invitation to Reflexive Sociology. Chicago: University of Chicago Press.

Bourdieu, P. (1993): Satz und Gegensatz. Frankfurt a. Main: Fischer.

Bourdieu, P./Wacquant, L. J. D. (1996): Reflexive Anthropologie. Frankfurt a. Main: Suhrkamp.

Bourdieu, P. (1997): Die männliche Herrschaft. In: I. Dölling and B. Krais, Ein alltägliches Spiel. Geschlechterkonstruktion in der sozialen Praxis. Frankfurt a. Main: Suhrkamp: 157-217.

Bourdieu, P. (1998): Die feinen Unterschiede. Kritik der gesellschaftlichen Urteilskraft. Frankfurt a. Main: Suhrkamp.

Bourdieu, P. (2001): Masculine Domination. Stanford: Stanford University Press.

Bourdieu, P. (2005): Die männliche Herrschaft. Frankfurt a. Main: Suhrkamp.

Bowen, D. E./Hisrich, R. D. (1986): The female entrepreneur: A career development perspective. In: Academy of Management Review, 11(2): 393-407.

Cleveland, J. N./Stockdale, M./Murhpy, K. R. (2000): Women and Men in Organizations. Mahwah u.a.: Lawerence Erlbaum Associates.

Correll, S. J. (2001): Gender and the Career Choice Process: The Role of Biased Self-Assessments. In: American Journal of Sociology, 106(6): 1691-1730.

Corsun, D. L./Costen, W. M. (2001): Is the Glass Ceiling Unbreakable? Habitus, Fields, and the Stalling of Women and Minorities in Management. In: Journal of Management Inquiry, 10(1): 16-25.

Durkheim, É. (2008): Über soziale Arbeitsteilung. Studie über die Organisation höherer Gesellschaften. Arbeitsteilung, Solidarität und Moral. Eine werkgeschichtliche und systematische Einführung in die 'Arbeitsteilung'. Frankfurt a. Main: Suhrkamp.

Eagly, A. H./Carley, L. L. (2007): Through the labyrinth: The truth about how women become leaders. Boston: Harvard Business School Press.

Eckes, T. (2004): Geschlechterstereotype: Von Rollen, Identitäten und Vorurteilen. In: R. Becker and B. Kortendiek, Handbuch Frauen und Geschlechterforschung. Theorie, Methoden, Empirie. Wiesbaden: VS Verlag für Sozialwissenschaften: 165-177.

Emirbayer, M./Johnson, V. (2008): Bourdieu and organizational analysis. In: Theory and Society, 37(1): 1-44.

Engler, S. (2004): Habitus und sozialer Raum: Zur Nutzung der Konzepte Pierre Bourdieus in der Frauen- und Geschlechterforschung. In: R. Becker and B. Kortendiek, Handbuch der Frauen- und Geschlechterforschung. Theorie, Methoden, Empirie. Wiesbaden: VS Verlag für Sozialwissenschaften: 222-233.

Farmer, H. S. (1985): Model of career and achievement motivation for women and men. In: Journal of Counseling Psychology, 32(3): 363-390.

Gaschke, S. (2005). Frauen werden männlicher, Die Zeit online, http://www.zeit.de/2005/21/Bilanz_Serie, access on July 23, 2009.

Granrose, C. S. (2007): Book Review: Handbook of Career Studies. In: Academy of Management Perspectives, 21(1): 88-90.

Gunz, H./Peiperl, M. (2007): Handbook of Career Studies. Los Angeles: Sage.

Halberstam, J. (1998): Female Masculinity. Durham: Duke University Press.

Helmreich, R. L./Spence, J. T./Wilhelm, J. A. (1981): A Psychometric Analysis of the Personal Attributes Questionnaire. In: Sex Roles, 7(11): 1097-1108.

Hermann, A. (2004): Karrieremuster im Management. Pierre Bourdieus Sozialtheorie als Ausgangspunt für eine genderspezifische Betrachtung. Wiesbaden: Deutscher Universitäts-Verlag.

Heslin, P. A. (2005): Conceptualizing and evaluating career success. In: Journal of Organizational Behavior, 26(2): 113-136. 
Hossiep, R./Paschen, M. (1998): Das Bochumer Inventar zur berufsbezogenen Persönlichkeitsbeschreibung (BIP). Handanweisung. Göttingen: Hogrefe Verlag für Psychologie.

Hughes, E. C. (1937): Institutional office and the person. In: American Journal of Sociology, 43: 404-413.

Iellatchitch, A./Mayrhofer, W./Meyer, M./Steyrer, J./Strunk, G./Erten, C. (2001): The field of career. Toward a new theoretical perspective. Paper presented at 17th Colloquium of the European Group of Organizational Studies (EGOS), Lyon, France.

Iellatchitch, A./Mayrhofer, W./Meyer, M. (2003): Career fields: A small step towards a grand career theory? In: International Journal of Human Resource Management, 14(5): 728-750.

Jennrich, R. I./Schluchter, M. D. (1986): Unbalanced repeated-measures models with structured covariance matrices. In: Biometrics, 42(4): 805-820.

Judge, T. A./Cable, D. M./Bourdeau, J. W./Bretz, R. D. (1995): An empirical investigation of the predictors of executive career success. In: Personnel Psychology, 48(3): 485-519.

Judge, T. A./Kammeyer-Mueller, J. D. (2007): Personality and Career Success. In: H. Gunz and M. Peiperl, Handbook of Career Studies. Los Angeles u. a.: Sage: 59-78.

Krais, B. (1985): Der Begriff des Habitus bei Bourdieu und seine Bedeutung für die Bildungstheorie. In: G. Frank, B. Dewe and W. Huge, Theorien der Erwachsenenbildung. München:

Lahire, B. (2003): From the habitus to an individual heritage of dispositions. Towards a sociology at the level of the individual. In: Poetics, 31(5): 329-355.

Leidner, R. (1991): Serving Hamburgers and Selling Insurance: Gender, Work, and Identity in Interactive Service Jobs. In: Gender \& Society, 5(2): 154-177.

Lemons, M. A./Danehower, V. C. (1996): Organizational justice and the glass ceiling: The moderating role of gender schemas. In: Academy of Management Proceedings: 398-402.

Lobel, S. A./St. Clair, L. (1992): Effects of family responsibilites, gender, and career identity salience on performance outcomes. In: Academy of Management Journal, 35(5): 1057-1069.

Lyness, K. S./Thompson, D. E. (1997): Above the glass ceiling? A comparison of matched samples of female and male executives. In: Journal of Applied Psychology, 82(3): 359-375.

Mallon, M./Cohen, L. (2001): Time for a change? Women's accounts of the move from organizational careers to self-employment. In: British Journal of Management, 12(3): 217.

Marshall, J. C. (1989): Re-visioning career concepts: A feminist invitation. In: M. B. Arthur, B. S. Lawrence and D. T. Hall, Handbook of career theory. Cambridge, UK: Cambridge University Press: 275-291.

Mayrhofer, W./Iellatchitch, A./Meyer, M. (2005): Career Habitus Revisited. Complicated and Incomrehensible Answers to Questions Nobody Asked? Paper presented at 21st Colloquium of the European Group of Organizational Studies (EGOS), Berlin, Germany.

Mayrhofer, W./Hofbauer, J./Iellatchitch, A./Meyer, M./Schneidhofer, T. M. (2007a): Making sense of career networking. Towards a qualitative approach to social capital. Paper presented at 23rd Colloquium of European Group of Organisational Studies (EGOS), Vienna, Austria.

Mayrhofer, W./Meyer, M./Steyrer, J. (2007b): Contextual Issues in the Study of Careers. In: H. Gunz and M. Peiperl, Handbook of Career Studies. Los Angeles u. a.: Sage: 215-240.

Mayrhofer, W./Meyer, M./Steyrer, J./Langer, K. (2007c): Can Expatriation Research Learn from Other Disciplines? The Case of International Career Habitus. In: International Studies of Management \& Organization, 37(3): 89-107.

Mayrhofer, W./Schneidhofer, T. M. (2009): The Lay of the Land. European Career Research and Its Future. In: Journal of Occupational and Organizational Psychology, 82(4): 721-737.

Mayrhofer, W./Steyrer, J./Chudzikowski, K./Demel, B./Schiffinger, M./Schneidhofer, T. M./Strunk, G. (2009): The Magic Third Wave. Gender and income - a longitudinal analysis of the Vienna Career Panel Project. Paper presented at Annual Meeting of the Academy of Management Chicago, IL.

McCulloch, C. E./Searle, S. R. (2001): Generalized linear and mixed models. New York, NY: Wiley \& Sons.

Melamed, T. (1995): Career success: the moderating effect of gender. In: Journal of Vocational Behavior, 47(1): 35-60. 
Müller, H. P. (1986): Kultur, Geschmack und Distinktion. In: Kölner Zeitschrift für Soziologie und Sozialpsychologie, Sonderheft 27: 163-190.

Nelson, D. L./Quick, J. C. (1985): Professional women: Are distress and disease inevitable? In: Academy of Management Review, 10(2): 206-218.

Ng, T. W. H./Eby, L. T./Sorensen, K. L./Feldman, D. C. (2005): Predictors of Objective and Subjective Career Success: A Meta-Analysis. In: Personnel Psychology, 58(2): 367-408.

Nicholson, N./DeWaal-Andrews, W. (2005): Playing to win: Biological imperatives, self-regulation, and trade-offs in the game of career success. In: Journal of Organizational Behavior, 26(2): 137-154.

OECD (2008). Education at a glance 2008. OECD indicators, http://www.oecd.org/dataoecd/23/46/41284038.pdf, access on June 30, 2009.

Özbilgin, M./Tatli, A. (2005): Understanding Bourdieu's Contribution to Organization and Management Studies. In: Academy of Management Review, 30(4): 855-869.

Peiperl, M./Gunz, H. (2007): Taxonomy of Career Studies. In: H. Gunz and M. Peiperl, Handbook of Career Studies. Los Angeles u. a.: Sage: 39-54.

Podsakoff, P. M./Organ, D. W. (1986): Self-reports in organizational research: Problems and prospectors. In: Journal of Management, 12(4): 531-544.

Powell, G. N./Mainiero, L. A. (1992): Cross-Currents in the River of Time: Conceptualizing the Complexities of Women's Careers. In: Journal of Management 18(2): 215-237.

Procter, I./Padfield, M. (1999): Work orientations and women's work: A critique of Hakim's theory of the heterogeinity of women. In: Gender, Work and Organization, 6(3): 152-162.

Reichel, A./Schiffinger, M./Chudzikowski, K./Demel, B./Mayrhofer, W./Schneidhofer, T. M./ Steyrer, J. (2006): Organising career success. An exploratory study of individuals' configuration of objective and subjective career success. Paper presented at 22nd Colloquium of European Group of Organizational Studies (EGOS), Bergen, Norway.

Rosenkrantz, P./Vogel, S./Bee, H./Broverman, I./Broverman, D. M. (1968): Sex-role Stereotypes and Self-concepts in College Students. In: Journal of Consulting and Clinical Psychology, 32(3): 287295.

Runge, T. E./Frey, D./Gollwitzer, P. M./Helmreich, R. L./Spence, J. T. (1981): Masculine (instrumental) and feminine (expressive) traits. A comparison between students in the United States and West Germany. In: Journal of Cross-Cultural Psychology, 12(2): 142-162.

Schermelleh-Engel, K./Moosbrugger, H./Müller, H. (2003): Evaluating the fit of structural equation models: test of significance and descriptive goodness-of-fit measures. In: Methods of Psychological Research Online, 8(2): 23-74.

Schiefle, U. (1990): Einstellung, Selbstkonsistenz und Verhalten. Göttingen: Hogrefe Verlag für Psychologie.

Schiffinger, M./Strunk, G. (2003): Zur Messung von Karrieretaktiken und ihrer Zusammenhänge mit Karriereerfolg und Karriereaspirationen. In: R. Hitzler and M. Pfadenhauer, Karrierepolitik. Beiträge zur Rekonstruktion erfolgsorientierten Handelns. Opladen: Leske \& Budrich: 295-313.

Schneidhofer, T. M./Schiffinger, M./Mayrhofer, W. (2009): Men and women - what else? Gender Role Types and their Effects on Objective Career Success over time. Paper presented at Annual Meeting of the Academy of Management, Chicago, IL.

Schruijer, S. G. L. (2006): Do Women Want to Break the Glass Ceiling? A Study of their Career Orientations and Gender Identity in The Netherlands. In: Management Revue, 17(2): 143-154.

Seibert, S. E./Kraimer, M. L. (2001): The Five-Factor Model of Personality and Career Success. In: Journal of Vocational Behavior, 58(1): 1-21.

Seibert, S. E./Kraimer, M. L./Liden, R. C. (2001): A social capital theory of career success. In: Academy of Management Journal, 44(2): 219-237.

Simpson, M. (1994): Here come the mirror men. In: The independent, 15 November.

Snyder, M. (1974): Self-Monitoring of Expressive Behavior. In: Journal of Personality and Social Psychology, 30(4): 526-537. 
Spence, J. T./Helmreich, R. L./Stapp, J. (1974): The Personal Attributes Questionnaire: A measure of sex-role stereotypes and masculinity-femininity. In: JSAS Catalog of Selected Documents in Psychology, 4(43): 617.

Spence, J. T./Helmreich, R. L./Stapp, J. (1975): Ratings of self and peers on sex role attributes and their relation to self-esteem and conceptions of masculinity and femininity. In: Journal of Personality and Social Psychology, 32: 29-39.

Spence, J. T./Helmreich, R. L. (1978): Masculinity and Femininity: Their Psychological Dimensions, Correlates, \& Antecedents. Austin: University of Texas Press.

Spence, J. T./Helmreich, R. L./Holahan, C. K. (1979): Negative and positive components of psychological masculinity and femininty and their relationships to self-reports of neurotic and acting-out behaviors. In: Journal of Personality and Social Psychology, 37(10): 1673-1682.

Spence, J. T. (1991): Do the BSRI and PAQ measure the same or different concepts? In: Psychology of Women Quarterly, 15(1): 141-165.

Spence, J. T./Buckner, C. E. (2000): Instrumental and Expressive Traits, Trait Stereotypes, and Sexist Attitudes: What Do They Signify? In: Psychology of Women Quarterly, 24(1): 44-62.

Stroh, L. K./Brett, J. M./Reilly, A. H. (1992): All the Right Stuff: A Comparison of Female and Male Managers. In: Journal of Applied Psychology, 77(3): 251-260.

Strunk, G./Hermann, A./Praschak, S. (2005): Eine Frau muss ein Mann sein, um Karriere zu machen. In: W. Mayrhofer, M. Meyer and J. Steyrer, Macht? Erfolg? Reich? Glücklich? Einflussfaktoren auf Karrieren. Wien: Linde international: 211-242.

Strunk, G./Hermann, A. (2009): Berufliche Chancengleichheit von Frauen und Männern. Eine empirische Untersuchung zum Gender Pay Gap. In: Zeitschrift für Personalforschung, 23(3): 237257.

Tharenou, P. (1999): Gender differences in advancing to the top. In: International Journal of Management Reviews, 1(2): 111-132.

Thomas, D. C./Inkson, K. (2007): Careers Across Cultures. In: H. Gunz and M. Peiperl, Handbook of Career Studies. London: Sage: 451-471.

Tsui, A. S./Gutek, B. A. (1984): A role set analysis of gender differences in performance, affective relationships, and career success of industrial middle managers. In: Academy of Management Journal, 27(3): 619-635.

West, C./Zimmerman, D. H. (1987): Doing gender. In: Gender \& Society, 1(2): 125-151.

Whithehead, S. (2008): Metrosexuality! Cameron, Brown and the plitics of 'new masculinity'. In: Public Policy Research, 14(4): 234-239.

Williams, C. (1992): The Glass Escalator: Hidden Advantages for Men in the "Female" Professions. In: Social Problems, 39(3): 253-267.

Williams, J. E./Bennett, S. M. (1975): The Definition of Sex Stereotypes via the Adjective Check List. In: Sex Roles, 1(4): 327-337.

Williams, J. E./Best, D. L. (1990): Measuring Sex Stereotypes: A Multination Study. Newbury Park, CA: Sage.

Zheng, B. (2000): Summarizing the goodness of fit of generalized linear models for longitudinal data. In: Statistics in Medicine, 19: 126-1275. 


\section{Appendix: Descriptive statistics on independent and dependent} variables

\begin{tabular}{|c|c|c|c|c|c|c|c|c|c|}
\hline $\begin{array}{l}1990 \\
\text { cohort }\end{array}$ & $\begin{array}{l}\text { Femininity } \\
\text { mean }\end{array}$ & $\begin{array}{l}\text { Masculinity } \\
\text { mean }\end{array}$ & $\begin{array}{l}\text { Income } \\
\text { years 1-7 }\end{array}$ & $\begin{array}{l}\text { Income } \\
\text { years 8-12 }\end{array}$ & & $\begin{array}{l}\text { Femininity } \\
\text { mean }\end{array}$ & $\begin{array}{l}\text { Masculinity } \\
\text { mean }\end{array}$ & $\begin{array}{l}\text { Income } \\
\text { years 1-7 }\end{array}$ & $\begin{array}{l}\text { Income } \\
\text { years 8-12 }\end{array}$ \\
\hline \multirow[t]{4}{*}{$\begin{array}{l}\text { Women } \\
(n=77)\end{array}$} & $3.71(.48)$ & $4.17(.69)$ & 28300 & 44934 & $\begin{array}{l}\text { Undiff. } \\
(n=20)\end{array}$ & $3.23(.30)$ & $3.55(.73)$ & 24366 & 39696 \\
\hline & & & & & $\begin{array}{l}\text { Feminine } \\
(\mathrm{n}=24)\end{array}$ & $4.00(.32)$ & $3.86(.31)$ & 26316 & 29937 \\
\hline & & & & & $\begin{array}{l}\text { Masculine } \\
(n=13)\end{array}$ & $3.30(.25)$ & $4.69(.30)$ & 28392 & 50039 \\
\hline & & & & & $\begin{array}{l}\text { Androgyn. } \\
(\mathrm{n}=20)\end{array}$ & $4.10(.26)$ & $4.80(.29)$ & 34943 & 65697 \\
\hline \multirow[t]{4}{*}{$\begin{array}{l}\text { Men } \\
(n=121)\end{array}$} & $3.53(.45)$ & $4.32(.51)$ & 33250 & 64682 & $\begin{array}{l}\text { Undiff. } \\
(\mathrm{n}=36)\end{array}$ & $3.18(.29)$ & $3.91(.38)$ & 32940 & 59739 \\
\hline & & & & & $\begin{array}{l}\text { Feminine } \\
(\mathrm{n}=21)\end{array}$ & $3.92(.26)$ & $3.89(.44)$ & 32301 & 46703 \\
\hline & & & & & $\begin{array}{l}\text { Masculine } \\
(\mathrm{n}=34)\end{array}$ & $3.29(.29)$ & $4.56(.19)$ & 34837 & 81630 \\
\hline & & & & & $\begin{array}{l}\text { Androgyn. } \\
(n=30)\end{array}$ & $3.97(.27)$ & $4.72(.29)$ & 32609 & 64140 \\
\hline $\begin{array}{l}2000 \\
\text { cohort }\end{array}$ & $\begin{array}{l}\text { Femininity } \\
\text { mean }\end{array}$ & $\begin{array}{l}\text { Masculinity } \\
\text { mean }\end{array}$ & $\begin{array}{l}\text { Income } \\
\text { years 1-7 }\end{array}$ & $\begin{array}{l}\text { Income } \\
\text { years 8-12 }\end{array}$ & & $\begin{array}{l}\text { Femininity } \\
\text { mean }\end{array}$ & $\begin{array}{l}\text { Masculinity } \\
\text { mean }\end{array}$ & $\begin{array}{l}\text { Income } \\
\text { years 1-7 }\end{array}$ & $\begin{array}{l}\text { Income } \\
\text { years 8-12 }\end{array}$ \\
\hline \multirow[t]{4}{*}{$\begin{array}{l}\text { Women } \\
(n=208)\end{array}$} & $3.83(.52)$ & $4.01(.66)$ & 33714 & & $\begin{array}{l}\text { Undiff. } \\
(n=65)\end{array}$ & $3.34(.40)$ & $3.46(.53)$ & 33020 & \\
\hline & & & & & $\begin{array}{l}\text { Feminine } \\
(n=61)\end{array}$ & $4.20(.28)$ & $3.76(.41)$ & 31938 & \\
\hline & & & & & $\begin{array}{l}\text { Masculine } \\
(n=42)\end{array}$ & $3.59(.27)$ & $4.60(.28)$ & 35507 & \\
\hline & & & & & $\begin{array}{l}\text { Androgyn. } \\
(n=40)\end{array}$ & $4.31(.30)$ & $4.68(.32)$ & 35699 & \\
\hline \multirow[t]{4}{*}{$\begin{array}{l}\text { Men } \\
(n=221)\end{array}$} & $3.82(.49)$ & $4.28(.56)$ & 44880 & & $\begin{array}{l}\text { Undiff. } \\
(n=60)\end{array}$ & $3.37(.34)$ & $3.69(.38)$ & 41247 & \\
\hline & & & & & $\begin{array}{l}\text { Feminine } \\
(n=40)\end{array}$ & $4.20(.25)$ & $3.91(.23)$ & 38623 & \\
\hline & & & & & $\begin{array}{l}\text { Masculine } \\
(n=50)\end{array}$ & $3.51(.32)$ & $4.68(.33)$ & 45997 & \\
\hline & & & & & $\begin{array}{l}\text { Androgyn. } \\
(n=71)\end{array}$ & $4.21(.26)$ & $4.70(.30)$ & 50854 & \\
\hline
\end{tabular}

